\title{
Investigation of Campylobacteriosis in Abort Cases in Kars Province by Pathological, Immunohistochemical, PCR and Microbiological Methods
}

\author{
Emin KARAKURT ${ }^{1}$, Hilmi NUHOĞLU ${ }^{1}$, Serpil DAĞ ${ }^{1}$, Aliye GÜLMEZ SAĞLAM ${ }^{2}$, Enver BEYTUT ${ }^{1}$, \\ Mitat ŞAHIN², Salih OTLU², Özgür ÇELEBİ ${ }^{2}$
}

${ }^{1}$ Kafkas University, Faculty of Veterinary Medicine, Department of Pathology, Kars/TURKEY

${ }^{2}$ Kafkas University, Faculty of Veterinary Medicine, Department of Microbiology, Kars/TURKEY

Key Words:

abortion

campylobacteriosis

cattle

microbiology

pathology

sheep

\section{Anahtar Kelimeler: \\ atik \\ kampilobakteriyozis \\ koyun \\ mikrobiyoloji \\ patoloji \\ siğır}

Received: 24.12.2019

Accepted: 22.06.2020

Published Online: 28.08.2020

Article Code: 673903

Correspondence:

E. KARAKURT

(mehmeteminkarakurt@hotmail.com)

ORCID:

E. KARAKURT : 0000-0003-2019-3690

H. NUHOĞLU : 0000-0003-2530-2542

S. DAG $\quad: 0000-0001-7667-689 \mathrm{X}$

AG. SAĞLAM : :0000-0002-7639-5075

E. BEYTUT :0000-0003-3360-2940

M. SAHIN :0000-0003-0106-5677

S. ÓTLU :0000-0001-8490-2279

Ö. ÇELEBİ : :0000-0002-3478-008X

\begin{abstract}
Campylobacteriosis is an infectious, zoonotic infection characterized by offspring and infertility, leading to economic losses in cattle and sheep breeding. In this study, we aimed to investigate the incidence of cattle and sheep abortion in Kars region in terms of Campylobacteriosis and evaluate the results by PCR, immunohistochemical, histopathological and microbiological methods. In this context, liver and lung tissue examples and abomasum contents of 444 abort cases brought from Kars Center and districts to Kafkas University Faculty of Veterinary Medicine Pathology Department between 2013 2019 years were examined. Tissue examples from animals were fixed in \% 10 buffered formaldehyde solutions. After routine procedures, paraffin blocks were prepared and sections with a thickness of $5 \mu \mathrm{m}$ were taken for Hematoxylin \& Eosin staining and $4 \mu \mathrm{m}$ were taken for immunohistochemical staining. Sections were examined under light microscope to determine histopathologic changes. Organs belonging to aborted fetuses and abomasum contents were inoculated into the Preston Campylobacter Enrichment Broth containing microbial study selective supplement, and then enriched by pre-enrichment and then passed through Preston Campylobacter Selective Agar. Cultures in which the culture was incubated after incubation were examined for colony morphology and microscopic appearance and Campylobacter spp. suspicious colonies were evaluated by biochemical tests. As a result of histopathologic studies, characteristically, 7 of 17 abortion cases with multifocal necrotic hepatitis pattern and yellow abomasum contents were blurred and clotted, PCR, immunhistochemical and microbiological methods detected as Campylobacter spp. positive towards the direction. As a result, we thought that Campylobacteriosis is an important place in the abortion cases from Kars region and should be taken into consideration in breeding.
\end{abstract}

\section{Kars İlinde Gözlenen Atık Vakalarında Kampilobakteriozisin Patolojik, İmmunohistokimyasal, PCR ve Mikrobiyolojik Yöntemler ile Araştırılması ÖZ}

Kampilobakteriyozis, sığır ve koyun yetiştiriciliğinde ekonomik kayıplara yol açan yavru atımı ve infertilite ile karakterize, bulașıcı ve zoonotik bir infeksiyondur. Bu çalıșmada, Kars yöresinde meydana gelen sığır ve koyun abort vakalarını Kampilobakteriyozis yönünden incelemek ve sonuçları PCR, immunohistokimyasal, histopatolojik ve mikrobiyolojik olarak değerlendirmek amaçlanmıștır. Bu kapsamda, 2013-2018 yılları arasında Kafkas Üniversitesi Veteriner Fakültesi Patoloji Anabilim Dalına Kars merkez ve ilçelerinden getirilen 444 adet atık vakasına ait karaciğger ve akciğer doku örnekleri ile abomazum içerikleri incelenmiștir. Hayvanlardan alınan doku örnekleri \% 10'luk tamponlu formaldehit solüsyonunda tespit edildi. Rutin ișlemlerin ardından hazırlanan parafin bloklardan, Hematoksilen Eozin boyaması için $5 \mu \mathrm{m}$, immunohistokimyasal boyama için kalınlı̆̆ında $4 \mu \mathrm{m}$ kesitler alındı. Histopatolojik değişikliklerin belirlenmesi amacıyla kesitler 1 șık mikroskobunda incelendi. Abort vakalarına ait organlar ve abomasum içerikleri mikrobiyolojik inceleme amacıyla selektif supplement içeren Preston Campylobacter Enrichment Broth içerisine inoküle edilerek ön zenginleştirmeye ve daha sonra Preston Campylobacter Selektif Agara geçilerek inkübe edildi. İnkübasyon sonrası üremenin olduğu kültürler koloni morfolojisi ve mikroskobik görünüm yönünden incelendi ve Campylobacter spp. yönünden şüpheli görülen koloniler biyokimyasal testlere tabi tutularak değerlendirildi. Yapılan histopatolojik incelemeler sonucunda karakteristik olarak hedef tahtası görünümünde multifokal nekrotik hepatitis tablosu gözlenen ve abomazum içeriği sarı renkte, bulanık ve pıhtı içeren 17 adet abort vakasının 7'si Camphylobacter ssp. yönünden PCR, immunohistokimyasal ve mikrobiyolojik yöntemlerle pozitif bulundu. Sonuç olarak Kars yöresinde meydana gelen atık vakaları içerisinde Kampilobakteriyozis'in önemli bir yeri olduğu ve yetiştiricilikte dikkate alınması gerektiği düş̧ünmekteyiz.

\section{INTRODUCTION}

Abortion in sheep and cattle can occur due to many reasons. These reasons can be infectious or non-infectious $(1,2)$. Among the causes of abortion due to infections, Campylobacteriosis is one of the main factors in many countries and causes significant economic losses in infected flocks. $(3,4)$. In addition to cattle and sheep abortions, Campylobacteriosis leads to abnormal 
oestrus cycle and decreased fertility (5). Campylobacter fetus (formerly Vibrio fetus) is a microaerophilic and gram negative organism $(6,7)$. C.fetus originally divided into three subspecies: C. fetus subsp. venerealis, C. fetus fetus and C. fetus subsp. testudinum $(8,9)$. Of these species, C.fetus subsp. venerealis causes enzootic infertility and abortion in cattle, while $C$. fetus fetus is associated with epizootic abortion in cattle and sheep (10). Campylobacter fetus species are important veterinary pathogens as well as infect humans (11). In this study, we aimed to present the cases of cattle and sheep abortion in Kars region between 20132019 years in terms of Campylobacteriosis and to evaluate the results by PCR, immunohistochemical, histopathological and microbiological methods.

\section{MATERIALS AND METHODS}

\section{Animals}

The material of the study consisted of liver and lung tissue samples and abomasum contents of 444 (188 cattle and 261 sheep) abort cases that were brought from Kars center and districts to Kafkas University Veterinary Faculty Pathology Department between 2013-2019 years.

\section{Bacterial isolation and phenotypic identification}

In this study, tissue samples taken from cattle and sheep abortions were examined. For isolation purposes, blood agar from various organs of abortion cases was transferred to Preston Campylobacter Selective Agar and incubated at $37^{\circ} \mathrm{C}$ and $42^{\circ} \mathrm{C}$ for $48-72$ hours. Breeding cultures were examined for colony morphology, microscopic appearance, catalase, oxidase and aerobic reproduction. (12,13). Campylobacter spp. The colonies that were suspected in terms of blood were purified by switching to Blood agar base no: 2 (CM271, Oxoid) medium (12,13). The purified colonies were transferred to Brucella broth containing $20 \%$ glycerol for subsequent molecular identification and stored at $-20^{\circ} \mathrm{C}$.

\section{DNA Extraction and Multiplex PCR}

The classical phenol-chloroform extraction method (14) was used for DNA extraction from the isolates and then multiplex PCR technique was applied on for Campylobacter spp. The primer sets targeting the $23 \mathrm{~S}$ rRNA gene of Campylobacter spp.

Each PCR tube for Campylobacter spp. contained 12,5 $\mu \mathrm{l}$ Taq DNA Polymerase 2x Master Mix 1.5 $\mu$ l 23S rRNA primer and $3 \mu \mathrm{l}$ of whole-cell template DNA. The volume was adjusted with sterile distilled water to give $25 \mu \mathrm{l}$. DNA amplification was carried out in a thermocycler using an initial denaturation step at $95^{\circ} \mathrm{C}$ for $6 \mathrm{~min}$ followed by 30 cycles of amplification (denaturation at $95^{\circ} \mathrm{C}$ for $0.5 \mathrm{~min}$, annealing at $59^{\circ} \mathrm{C}$ for 0.5 min, and extension at $72^{\circ} \mathrm{C}$ for $0.5 \mathrm{~min}$ ), and was finalized with an extension at $72^{\circ} \mathrm{C}$ for $7 \mathrm{~min}$.

The PCR reaction is accompanied by the Campylobacter reference strains and the amplified products were visualised by $1.5 \%$ agarose jel electrophoresis and the images were photographed under UV transilluminator (UVP, CA 91786, U.S.A.).

\section{Histopathological Investigations}

Tissue samples from animals were fixed in \% 10 buffered formaldehyde solution (Merck). Paraffin blocks were prepared ater routine tissue procedures and $5 \mu \mathrm{m}$ thick sections were obtained for Hematoxylin \& Eosin (H\&E) staining. In order to determine the histopathological changes, the sections were examined by light microscope (Olympus Bx53) and photographed with Cell ${ }^{\wedge} \mathrm{P}$ Program (Olympus Soft Imaging Solutions $\mathrm{GmbH}, 3,4)$.

\section{Immunohistochemical Investigations}

Avidin-Biotin Peroxidase method was used as immunohistochemical stain. For immunohistochemical staining, sections of $4 \mu \mathrm{m}$ thick from paraffin blocks were rehydrated. In order to prevent endogenous peroxidase activity, the sections were treated with 3\% hydrogen peroxide solution for 15 minutes. Then, the microwave method was applied to the sections to reveal the antigenic receptors (Citrat Buffer Solution $\mathrm{pH} 6$ for $25 \mathrm{~min})$. In order to prevent nonspecific staining, the sections were incubated for $30 \mathrm{~min}$ with nonimmune serum (Genemed Biotechnologies REF 54-0003). Following treatment with Phosphate Buffered Salt Solution (PBS) with $1 / 50$ of diluted antibody (Accurate Chemical \& Scientific Corporation; Cat No: QRL01-92-93) were incubated for over night $\left(+4{ }^{\circ} \mathrm{C}\right.$ in refrigerator $)$. The sections were washed 3 times in PBS solution for 5 minutes, and the biotinised secondary antibody (Genemed Biotechnologies REF 54-0003) were applied to them at room temperature for 30 minutes. After washing in PBS (3-5 min), all sections were incubated with peroxidase-bound Strep Avidin (Genemed Biotechnologies REF 54-0003) for 30 minutes. A solution of 3.3-diaminobenzidine tetra hydrochloride (DAB) (Genemed Biotechnologies REF 10-0048) were used as colour revealing substrate. The sections were stained with Mayer Hematoxylin and coated with immune mount.

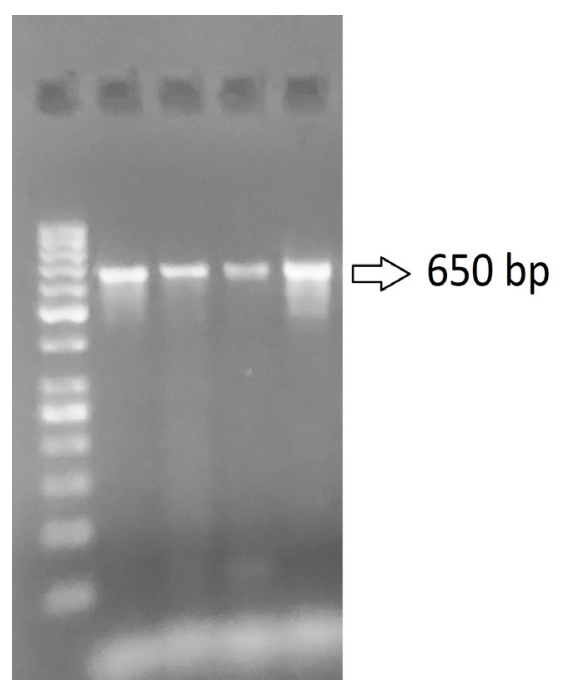

Figure 1. Gel electrophoresis image of m-PCR for Campylobacter spp. 1: DNA marker (Gene ruler 50 bp DNA Ladder, Fermentas); 2-4: Positive samples; 5: Positive control for Campylobacter spp. 


\section{RESULTS}

\section{Isolation Results}

As a result of cultural examination colonies of the Campylobacter spp. were isolated showing microscopic characteristics such as

\section{Macroscopic Results}

A small amount of fluid was observed in the abdominal and thoracic cavities with gelatinous and sometimes serous subcutaneous edema. Abomasum contents were determined to be fuzzy and clotted. From 1-2 mm to 1-2 cm, a large number

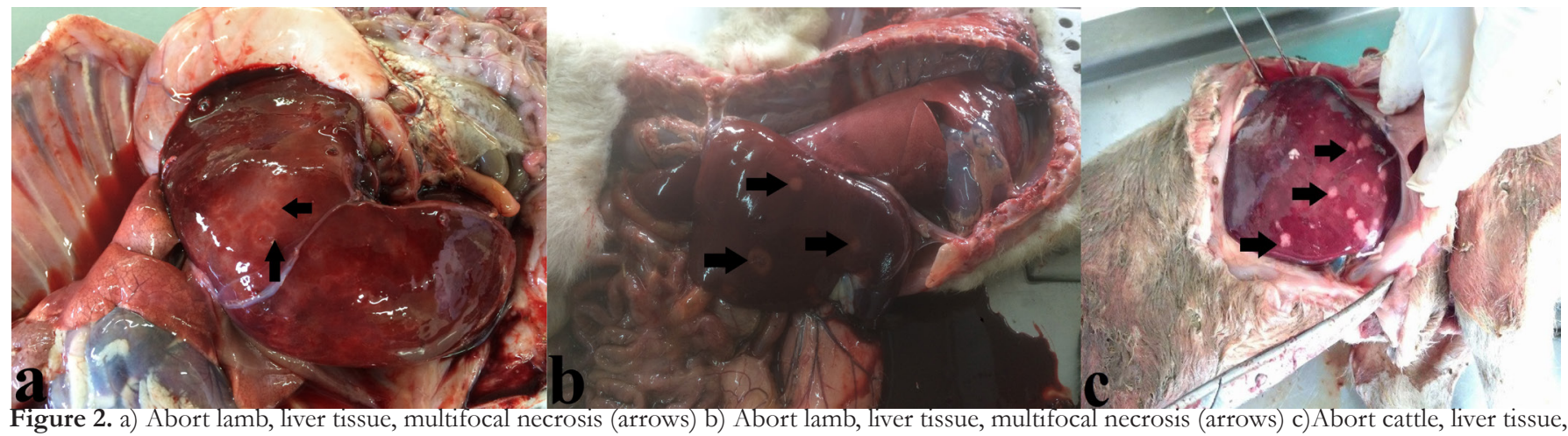
multifocal necrosis (arrows)

small size, pinpoint morphology, non-hemolytic, and Gramnegative "gull-wing" shaped bacilli. Suspected isolates were subjected to biochemical tests. Thus, Campylobacter spp. was isolated in $7(\% 1.58)$ of the 444 aborted fetuses. Of the 7 positive Campylobacter cases, 6 were sheep ( $\% 2.30$, total 261 cases) and only 1 were cattle (\%0.55, total 183 cases) specimens. of grizzly white foci are detected in liver. We detected that the central part of these lesions was light brown and collapse,while the outer part was slightly raised and pale (Figure 2a, 2b, 2c).

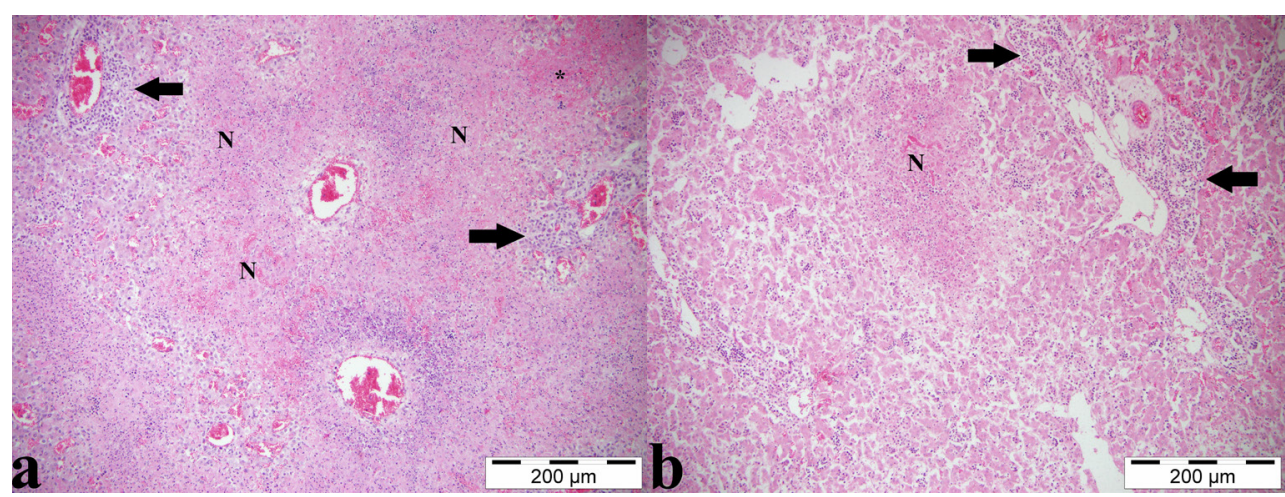

Figure 3. a: Liver tissue, multifocal necrosis $(\mathrm{N})$, hemorrhage $(*)$, mononuclear cell infiltration (arrows), Bar: $200 \mu \mathrm{m}, \mathrm{H} \& \mathrm{E}$ b: Liver tissue, necrosis $(\mathrm{N})$, hemorrhage $(*)$, mononuclear cell infiltration (arrows), Bar: $200 \mu \mathrm{m}, \mathrm{H} \& \mathrm{E}$

\section{PCR Results}

7 isolates (6 sheep and 1 cattle), which were phenotypically characterized, were identified as Campylobacter spp. by using PCR. (Figure. 1).

\section{Histopathological Results}

We observed that multiple necrotic foci in the liver. In addition to these necrosis foci, a severe mononuclear cell infiltration was detected around the vessels. Hemorrhage was another finding in addition to multiple necrosis foci and perivascular mononuclear cell infiltrations (Figure 3a, 3b).

\section{Immunohistochemical Results}

We determined Campylobacter spp. immunoreactivity, especially in the cytoplasm of hepatocytes around multifocal necrosis areas in the liver. We also observed brownstained positive reactions in hepatocytes in the middle of necrotic areas (Figure 4a, 4b, 4c, 4d).

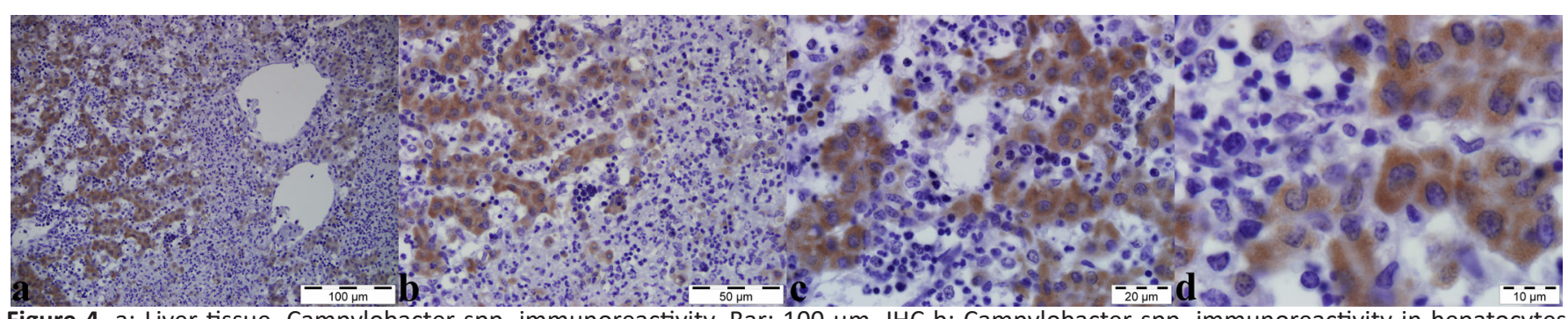

Figure 4. a: Liver tissue, Campylobacter spp. immunoreactivity, Bar: $100 \mu \mathrm{m}$, IHC b: Campylobacter spp. immunoreactivity in hepatocytes around the necrosis, Bar: $50 \mu \mathrm{m}$, IHC c: Brown positive reaction in the cytoplasm of hepatocytes, Bar: $20 \mu \mathrm{m}$, IHC d: Higher magnification, brown positive reaction in the cytoplasm of hepatocytes, Bar: $10 \mu \mathrm{m}, \mathrm{IHC}$ 


\section{DISCUSSION}

Campylobacter fetus is a curved, motile, non-spore-forming Gram-negative bacillus with one or two polar flagella, and is highly contagious zoonosis causing abortions in cattle and sheep (\%5-10) and diarrhea and systemic diseases in elderly and immunocompromised humans $(2,4,5)$.

Bovine genital campylobacteriosis is characterized by temporary infertility with mild endometritis, repetition of oestrus, early embryonic deaths and to a lesser extent abortions in the female (15-17). Campylobacteriosis is economically important for cattle breeding worldwide (18). Bovine venereal campylobacteriosis is arises from carrier bulls, but infection can also spread during artificial insemination(6). Campylobacteriosis causes endometritis and salpingitis in cows and heifers as a result of bacteria spreading to uterus and oviducts (19-20). Abortions may occur at any time during pregnancy, but are most commonly observed within a period of 6 to 8 months (21). Variable postmortem changes and histopathological changes such as neutrophilic bronchopneumonia, neutrophilic serositis, fibrinous peritonitis and rarely abomazitis may be observed in aborted fetuses $(7,15,22,23)$. Fetuses in the liver ranging from $1-2 \mathrm{~mm}$ to $1-2 \mathrm{~cm}$, randomly spread, varying number of light and colored foci are encountered. The inner parts of these lesions are light brownish decadent and the outer parts are slightly puffy and pale. Microscopic investigations show single cell necrosis with karyomegaly in hepatocytes or necrosis foci in severe cases and mononuclear cell infiltration around these foci $(21,22)$. Campylobacteriosis is highly contagious in sheep. It is characterized by abortions, stillbirths, weak and premature births in the last trimester of pregnancy $(24,25)$. Animals are infected by ingesting contaminated feces on feed and water from infected carrier animals (4). The organism colonizes the intestinal tract of animal, usually without clinical symptoms of diarrhea. A bacteremia may occur in susceptible pregnant sheep causes metritis and placentitis. Placental infections usually lead to fetal septicemia previous to abortions (10,26). Macroscopically, there is gelatinous, sometimes serous subcutaneous edema in the abort fetuses and a slightly bloody fluid in the abdominal and thoracic cavity. The fetus is usually autolytic (10). Similar to previous studies $(10,15)$, we also observed a small amount of fluid in the abdominal and thoracic cavities with gelatinous and sometimes serous subcutaneous edema. In addition, abomasum contents were determined to be fuzzy and clotted. However, the findings in the fetal liver are characteristic (27). Multifocal, pale-white, circular to targetoid necrotic foci in the liver up to $2 \mathrm{~cm}$ in diameter is the most diagnostic gross lesion but this lesion is not pathognomonic for Campylobacter abortions (17). Consistent with literature data $(17,27)$, we also detected from $1-2 \mathrm{~mm}$ to $1-2 \mathrm{~cm}$, a large number of grizzly white necrotic foci in fetal liver. We found that the central part of these lesions was light brown and collapse, while the outer part was slightly raised and pale. Microscopically, lesions characterized by widespread coagulation necrosis foci, mononuclear cell infiltrations, sinusoidal dilatation and hemorrhage were detected in the abort fetus liver. Lighter lesions were observed in the lung $(26,28)$. Similar to literature data $(21,22,26,28)$, we also observed that multiple necrosis foci in the liver. In addition to these necrotic foci, a severe mononuclear cell infiltration was detected around the vessels. Hemorrhage was another finding in addition to multiple necrosis foci and perivascular mononuclear cell infiltrations. Incompatible with literature data $(7,15,22,23)$ we didn't observe neutrophilic bronchopneumonia in the fetal lung. Consistent with previous studies (21) we determined Campylobacter spp. immunoreactivity, especially in the cytoplasm of hepatocytes around multifocal necrosis areas in the liver. We also observed brown-stained positive reactions in hepatocytes in the middle of necrotic areas.

Arda et al. (1987) isolated \%7.5 Campylobacter fetus from aborted sheep in Central Anatolia Region (29). Erdoğan et al. (1993) isolated \%2.7 Campylobacter fetus from aborted sheep and goats in Thrace Region (30). Güler et al. (1998) isolated $\% 8.51$ Campylobacter fetus subsp. fetus from aborted sheep in Konya (31). Sağlam et al. (1998) found \% 3.57 Campylobacter fetus subsp. from aborted sheep fetus in Erzurum and \%1.04 from aborted bovine fetuses and \% 5.70 from aborted sheep fetuses in Kars (23). Muz et al. (1999) isolated and identified Campylobacter fetus subsp. fetus from aborted sheep and goats in Elazı̆̆ and its borders (28). Karaman and Küçükayan (2000) isolated \%1.3 Campylobacter fetus subsp. fetus from aborted sheep in 17 different provinces (32). Gürtürk et al. (2000) found $23.5 \%$ Campylobacter antibodies from sheep blood sera in Van (33). Küçükayan et al. (2007) found $7.44 \%$ in sheep blood sera and $01.29 \%$ in fetuses as Campylobacter spp. in Ankara (34). Yeşilmen and Gül (2007) investigated \% 10 Campylobacter spp. from aborted sheep fetuses in Diyarbakir and its borders (24). Tuzcu et al. (2011) found \%6.6 Campylobacteriosis from abort bovine fetuses by immunohistochemical, microbiological and Real Time PCR in Adana and its borders (21). Büyük et al. (2011) found in \%10.25 in sheep and goat fetuses as Campylobacter coli in Kars (35). In our study, In our study, we found Campylobacter spp. to be positive by immunohistochemical, microbiological and PCR methods in 7 (\%1.58) of 444 cattle and sheep abort fetuses. Of the 7 positive Campylobacter cases, 6 were sheep $(\% 2.30$, total 261 cases) and only 1 were cattle $(\% 0.55$, total 183 cases) specimens.

The most important problem of sheep and cattle breeding is abortion (35). Infectious ovine abortions occur due to various bacterial, viral and protozoal agents (10). Most of the factors causing abort in sheep and bovine are of bacterial origin $(21,34)$. It has been shown that the majority of abortions in sheep and cattle breeding are related to Brucellosis, Campylobacteriosis, Listeriosis, Salmonellosis, Leptospirosis, Chlamydiosis $(21,33)$. In particular, most of these diseases are zoonosis and pose an important threat to human health (28). Campylobacteriosis is a highly contagious and zoonotic disease (24). It is known that the source of infection in humans is products from sheep and cattle. In order to prevent and control the disease, the causative agent must be diagnosed quickly and reliably (4). Many different techniques such as serology, PCR, immunohistochemistry and immunofluorescence staining are used in the diagnosis of this disease (24). The old methods used in the diagnosis of campylobacteriosis are time-consuming and partly difficult and do not always give correct results. In particular, PCR has been reported to be used in current studies 
for the diagnosis of campylobacteriosis and provides reliable results (4). In our study, we aimed to evaluate old and new methods together. Although there is no difference in molecular and immunohistochemical results, it is more advantageous to use PCR in the diagnosis of this disease for faster and more reliable results $(4,21)$. Only 7 of 17 abortion cases with multifocal, pale-white, circular to targetoid necrotic foci in the liver up to $2 \mathrm{~cm}$ in diameter is positive for Campylobacter spp. We thought that the remaining 10 cases gave negative results because of autolysis, placenta was not brought with abort or other enfectious agents such as Flexispira rappini (17).

Kars is an important sheep and cattle breeding region. We believe that reliable and rapid methods such as PCR should be used in the diagnosis of this disease in order to eliminate the economic losses due to abort and to protect human health. In addition, it is obvious that the disease will be detected more effectively if the specimens are delivered to us correctly and on time. For this reason, it is essential to inform the persons dealing with animal husbandry about abortive diseases. In conclusion according to the data of our study; we noted that Campylobacteriosis infection has an important role in the abortion cases in Kars.

\section{ACKNOWLEDGMENTS}

This study was presented as orally in 9th National Veterinary Pathology Congress (25th-25th October 2018, Antalya-Turkey)

\section{CONFLICTS OF INTEREST}

The authors declare no conflicts of interest with respect to the publication of this manuscript.

\section{REFERENCES}

1. Hamali H, Fallah S, Joozani RJ, Zare P, Noorsaadat G. Detection of Campylobacter spp. in sheep aborted fetuses by PCR. TLS 2014;3(2):49-56.

2. Silveira CDS, Fraga M, Giannitti F, Macías-Rioseco M, RietCorrea F. Diagnosis of Bovine Genital Campylobacteriosis in South America. Front Vet Sci. 2018;5:321.

3. Kreuder AJ, Lashley V, Yaeger M, Schleining JA, Plummer PJ. Histopathology and Spatial Distribution of Putative Growth Factors in Relation to Bacterial Localization of Campylobacter jejuni Within the Ovine Gallbladder. Front Vet Sci. 2019;6:226.

4. Hossein Abadi E, Saadati D, Najimi M, Hassanpour M. Molecular epidemiology of Campylobacter Fetus in aborted fetuses of Baluchi sheep in Sistan region. IJVST 2018;10(1): 47-52.

5. Campos-Múzquiz LG, Méndez-Olvera ET, ArellanoReynoso B, Martínez-Gómez D. Campylobacter fetus is Internalized by Bovine Endometrial Epithelial Cells. Pol J Microbiol. 2019;68(2):217-24.

6. Zhao H, Liu H, Du Y, Liu S, Ni H, Wang Y, et al. Development and evaluation of an indirect enzyme-linked immunosorbent assay for the detection of antibodies against Campylobacter fetus in cattle. Res Vet Sci. 2010;88(3):446-51.

7. Campero CM, Anderson ML, Walker RL, Blanchard PC, Barbano L, Chiu P, et al. Immunohistochemical identification of Campylobacter fetus in natural cases of bovine and ovine abortions. J Vet Med B Infect Dis Vet Public Health. 2005;52(3):138-41.

8. Hum S, Quinn K, Brunner J, On SL. Evaluation of a PCR assay for identification and differentiation of Campylobacter fetus subspecies. Aust Vet J. 1997;75(11):827-31.

9. GilbertMJ, Duim B, van der Graaf-van Bloois L, WagenaarJA, Zomer AL. Homologous Recombination between Genetically Divergent Campylobacter fetus Lineages Supports HostAssociated Speciation. Genome Biol Evol. 2018;10(3):716-22.

10. Fiorentino MA, Stazionati M, Hecker Y, Morsella C, Cantón G, Hernán Romero $\mathrm{H}$, et al. Campylobacter fetus subsp. fetus ovine abortion outbreak in Argentina. REDVET 2017;18(11):1-11

11. Iraola G, Hernández M, Calleros L, Paolicchi F, Silveyra S, Velilla A, et al. Application of a multiplex PCR assay for Campylobacter fetus detection and subspecies differentiation in uncultured samples of aborted bovine fetuses. J Vet Sci. 2012;13(4):371-6.

12. Skirrow MB, Benjamin J. '1001' Campylobacters: cultural characteristics of intestinal campylobacters from man and animals. J Hyg (Lond). 1980;85(3):427-42.

13. Vandamme P, Goossens H. Taxonomy of Campylobacter, Arcobacter and Helicobacter: A review. Zentralbl Bakteriol. 1992; 276(4):447-72.

14. Sambrook J, Russell D. Molecular Cloning: A Laboratory Manual. 3rd ed. New York: Cold Spring Harbor Laboratory Press; 2001.

15. Mahajan V, Banga HS, Gupta A. Immunohistochemical and Molecular Approaches for the Diagnosis of Campylobacter fetus subsp. venerealis in Natural Cases of Bovine Abortion. Proc. Natl. Acad. Sci. India, Sect. B Biol. Sci. 2015;85(2):673-7.

16. Jimenez DF, Perez AM, Carpenter TE, Martinez A. Factors associated with infection by Campylobacter fetus in beef herds in the Province of Buenos Aires, Argentina. Prev Vet Med. 2011;101(3-4):157-62.

17. Sahin O, Yaeger M, Wu Z, Zhang Q. CampylobacterAssociated Diseases in Animals. Annu Rev Anim Biosci. 2017;5(1):21-42.

18. Brooks BW, Devenish J, Lutze-Wallace CL, Milnes D, Robertson RH, Berlie-Surujballi G. Evaluation of a monoclonal antibody-based enzyme-linked immunosorbent assay for detection of Campylobacter fetus in bovine preputial washing 
and vaginal mucus samples. Vet Microbiol. 2004;103(1-2):7784.

19. Truyers I, Luke T, Wilson D, Sargison N. Diagnosis and management of venereal campylobacteriosis in beef cattle. BMC Vet Res. 2014;10:280.

20. Ak S, Turan N, Ak K, İleri İK, Ilgaz AA. Use Of Elisa, Ifa, And Avidin-Biotin Staining For The Diagnosis Of Bovine Genital Campylobacteriosis. Turk J Vet Anim Sci. 2000; 24(24):113-21

21. Tuzcu M, Oruç E, Tuzcu N, Yoldaş A, Yığın A. Atık Sı̆̆ır Fetüslerinde Kampilobakteriozisin Patolojik Immunohistokimyasal Mikrobiyolojik ve Gerçek Zamanlı PZR ile Teşhisi. Kafkas Univ Vet Fak Derg. 2010;16(3):509-14.

22. Morrell EL, Barbeito CG, Odeón CA, Gimeno EJ, Campero CM. Histopathological, immunohistochemical, lectinhistochemical and molecular findings in spontaneous bovine abortions by Campylobacter fetus. Reprod Domest Anim. 2011;46(2):309-15.

23. Sağlam YS, Türkütanıt SS, Taştan R, Bozoğlu H, Otlu S. Kuzeydoğu Anadolu Bölgesi'nde görülen bakteriyel sığır ve koyun abortlarının etiyolojik ve patolojik yönden incelenmesi. Vet Bil Derg. 1998;14(2):133-45.

24. Yeşilmen S, K Gül. Isolation, identification and antibiotic susceptibility of Campylobacter spp. in aborted sheep fetuses. Medycyna Wet. 2007; 63(10):1184-6

25. Yardimc1 H, Boynukara B, Akan M, Diker KS. Van çevresindeki koyunlarda Campylobacter antikorlarının ELISA ile saptanmas1. YYÜ Vet Fak Derg. 1998;9(1-2):5-8.

26. Robert B, Moeller Jr. Disorders of Sheep and Goats. In: Njaa BL, editor(s). Kirkbride's Diagnosis of Abortion and Neonatal Loss in Animals. 4th ed. Chichester: Wiley-Blackwell; 2012. p. 62-64.

27. Ay SS, Gürler H, Önyay F, Fındık A. Küçük ruminantlarda abortus sorunu ve reprodüktif aşılama programları. Turkiye Klinikleri J Vet Sci Obstet Gynecol-Special Topics. 2017;3(2):129-36.

28. Muz A, Ertaş HB, Öngör H, Gülcü HB, Özer H, Eröksüz H, et al. Elazı̆̆ ve çevresinde koyun ve keçilerde abortus olgularının bakteriyolojik, serolojik ve patolojik olarak incelenmesi. Tr J of Veterinary and Animal Sciences 1999;23(1):177-88.

29. Arda M, Bisping W, Aydın N, İstanbulluoğlu E, Akay Ö, İzgür M, et al. Orta Anadolu bölgesinde koyunların abortus olgularının etiyolojisi ve serolojisi üzerinde bir çalışma. A.Ü. Vet Fak Derg. 1987;34:195-206.

30. Erdoğan I, Gürel A, Tekin C, Uyanık F, Bitgel A. Trakya bölgesinde koyun keçi ve sığırlarda bakteriyel abortların tespiti ve dağılımı. Pendik Mikrobiyol. Derg. 1993;24(1):23-35.
31. Güler L, Gündüz K, Baysal T. Konya Veteriner Kontrol Araştırma Enstitüsüne getirilen koyun atık materyallerinin bakteriyolojik ve serolojik muayene sonuçlarının değerlendirilmesi. Veterinarium 1998;9(1):3-10.

32. Karaman Z, Küçükayan U. 1993-1997 yılları içinde Enstitümüze gönderilen atık yapan koyun kan serumları ve materyallerinin serolojik ve mikrobiyolojik yoklama sonuçları. Etlik Vet Mikrob Derg. 2000;11(1-2):23-30.

33. Gürtürk K, Solmaz H, Ekin İH, Aksakal A, Gülhan T. Van ve yöresinde yavru atan koyunlarda bakteriyolojik ve serolojik incelemeler. YYÜ Vet Fak Derg. 2000; 11(2):19-22.

34. Küçükayan U, Dakman A, Ülker U, Müştak K. Koyun kan serumları ve fetuslarının bakteriyel atık etkenleri yönünden incelenmesi. Etlik Vet Mikrob Derg. 2007; 18:11-16.

35. Büyük F, Çelebi Ö, Şahin M, Ünver A, Tazegül E. İki farklı koyun ve keçi sürüsünde Brucella ve Campylobacter ortak enfeksiyonu. Kafkas Univ Vet Fak Derg. 2011;17(Suppl A):177-180. 